\title{
Denosumab Experience in Metastatic Giant Cell Tumor of Bone: Case Series
}

\section{Metastatik Dev Hücreli Kemik Tümöründe Denosumab Deneyimi: Olgu Serisi}

\author{
Ahmet Şiyar Ekinci, Onur Eşbah, Ayşe Demirci, Tahsin Özatlı, Umut Demirci, Burçin Budakoğlu, Öznur Bal, \\ Ömür Berna Öksüzoğlu
}

Dr. A. Y. Ankara Onkoloji Eğitim Ve Araştırma Hastanesi, Tıbbi Onkoloji Kliniği, Ankara, Türkiye

Dergiye ulaşma tarihi:27/08/2014, Dergiye kabul tarihi:18/12/2014, DOI: 10.5505/aot.2014.38358

\section{ÖZET}

Dev hücreli kemik tümörü (DHKT) nadir görülen bir primer kemik tümörüdür. Günümüzde anti osteoklastik aktiviteye sahip bifosfanat tedavisi kullanılmaktadır. Denosumab tamamen insan kaynaklı monoklonal antikordur ve metastatik DHKT'de hastalık progresyonunu inhibe eder. Akciğer metastazı olan 3 DHKT'li hastayı özetledik. Hastalar 12 ile 18 ay arasında denosumab kullanmışlardı. Tedavi kesilmesinde sonraki 6 ile 15 aylık takipte hastalık progresyonu görülmedi. Hastalık yavaş seyirli olması nedeniyle takip süremiz kısa olabilir ancak bu konuda önemli bir deneyim olduğunu düşünmekteyiz.

Anahtar Kelimeler: Denosumab; Dev hücreli kemik tümörü; Akciğer metastazı

\begin{abstract}
Giant cell tumor of bone (GCTB) is a rare primary tumor of the bone. Bisphosphonate therapy is curently used in GCTB because of its anti-osteoclastic effects. Denosumab is fully human monoclonal antibody that inhibits disease progression in metastatic GCTB. We summarized three GCTB patients with lung metastasis. The patients received denosumab between 12-18 months and no disease progression between 6-15 months after discontinuation of treatment. Due to the indolent nature of the tumor follow-up period may be short, however we thinks it is an important experience for this issue.
\end{abstract}

Key words: Denosumab; Giant cell bone tumor; Lung metastasis

\section{Introduction}

Giant cell tumor of bone (GCTB) is a rare benign primary tumor of the bone accounting for about $5-35 \%$ of all primary bone tumors, with a strong tendency for local recurrence and that may metastasize to the lung $(1,2)$. GCTB usually occurs between 20-40 years of age. Wide excision and intralesional curettage are the two surgical treatment options for patients with resectable tumors $(3,4)$. Postoperative radiation therapy (RT) may decrease local failure and improve disease-free survival (5). When pulmonary involvement is diagnosed, if feasible surgery may be considered, because prognosis remains favorable in $80 \%$ of cases (6). About $20 \%$ of patients with metastasis of the continuously slow growing types and rapidly growing types would die of their disease if untreated.

Bisphosphonate therapy is currently used in GCTB because of its anti-osteoclastic effects. Denosumab is fully human monoclonal a receptor activator of nuclear factor $\mathrm{kB}$ ligand (RANKL) antibody. In a recent phase II study, denosumab given to patients with surgically salvageable and unsalvageable GCTB was well tolerated and associated with inhibited disease progression $(99 \%)$ and a reduced requirement for surgery (7). We summarized three GCTB patients with lung metastases that receiving denosumab.

\section{Case Reports}

Denosumab was administered by subcutaneous injection at $120 \mathrm{mg}$ every 4 weeks, with an 
additional loading dose of $120 \mathrm{mg}$ on days 8 and 15 of the first cycle. All patients received calcium and vitamin D supplementation during therapy.

First Patient; A 32 years old female patient was admitted with a lump in her right wrist. First, in 2010, had been excised. Pathological examination was determined a GCTB. Later, due to local recurrence resection had been performed 3 times. RT had not been indicated. In December 2012, the patient was admitted with complaint of dyspnea. Thorax computarized tomography (CT) revealed multiple metastatic lesions that the large one was $14 \mathrm{~mm}$ size in the left lower lobe posteriorly. The patient was treated with 3 cycles denosumab. Radiologically partial regression was observed. At follow-up nodule size remained stable during therapy. Denosumab treatment was continued for 18 months. The patients is still without disease progression after $12^{\text {th }}$ months from end of treatment

Second Patient; A 30 years old female patient admitted to orthopedics clinic for a lump in her left wrist in April 2008. Local exicision had been performed. In pathological examination GCBT was revealed. Than two times local excision had been performed because of recurrence in March 2009 and January 2010. After last operation, RT had been performed. In September 2010 she admitted with dispnea, multıple metastasis was detected by CT. Palliative chemotherapy (adriamycin and cyclophosphamide alternating with ifosfamide, adriamycin) was administered for four cycles. Stable response was obtained after treatment. The patient became pregnant in the $6^{\text {th }}$ month at the end of chemotherapy. The patient gave birth to a healthy baby with no problem during the pregnancy period. Progression were detected in the lung metastases after third month of birth. Denosumab was administered in September 2012. After third month of treatment, partial regresion was detected. Regresion was ongoing after sixth month. Then stable response was detected. Denousmab was continued for 15 months. The patient has no symptom for 6 month after discontinuation of therapy.

Third Patient; A forty-one years old female patient was inspected for hip pain in January 2011. Magnetic resonance imaging (MRI) revealed a mass lesion in the left iliac bone. Tumor was curetted. Pathological examination revealed GCTB. The patients had no respiratory symptoms. Diffuse nodular lesions were seen in both lungs in the screening thorax CT, the largest one was 3.5 $\mathrm{cm}$ size neighborhood of the left lower lobe bronchus. Palliative surgery performed because of fracture risk in the hip. Zoledronic acid was administered 3 cycles in 3 months. Stable response was obtained. Then 12 months denosumab administered. After 3 months partial regression was detected. Stable response was detected in the others controls. The patients have no progressions after discontinuation of denosumab treatment after 15 months.

\section{Discussion}

In metastatic or unresectable GCTB, the use of medical treatment such as cytotoxic chemotherapy has been reported but there is a little data in literature. Chemotherapy have modest activity $(2,6)$. Bisphosphonates prevent bone resorption by inhibiting octeoclast activity and promoting osteoclast apoptosis. Balke reported the largest series evaluating the efficacy of bisphosphonates (8). Among 25 patients, 22 patients had stable disease after median follow-up 24 months. In a the phase II trial denosumab evaluated in recurrent or unresectable GCTB patients. Of the 37 patients 22 patients had resporse that evaluated by histology or radiology (7). The ongoing trials have been evaluated denosumab in the neoadjuvant setting.

There is some unresolved questions about denosumab treatment in GCTB. How long treatment should we give? When should surgery be considered in patients that metastasis restricted well after denosumab treatment? What is the risk of relapse after interruption the therapy? These questions are difficult questions that must be answered in clinical practise. In our experience one patient after 6 months and the others above 12 months did not relapse after discontinuation of denosumab therapy. Due to the indolent nature of the tumor follow-up period might be short, however we think it is an important experience for this condition. The optimal duration of treatment is unknown. In relapsed patients there is no data on the effectiveness of reinduction. Due to the limited number of 
patients; we think case reports are important for exhibiting accumulation of data and a common approach.

\section{Conflict of Interest: None}

\section{References}

1. Dominkus M, Ruggieri P,Bertoni F, et al. Histologically verified lung metastases in benign giant cell tumours-14 casesfrom single institution. Int Orthop 2006;30:499-504

2. Viswanathan S, Jambhekar NA. Metastatic giant cell tumor of bone: are there associated factorsand best treatment modalities? Clin Orthop Relat Res 2010;468:827-33

3. McDonald DJ, Sim FH, McLeod RA, Dahlin DC. Giant-cell tumor of bone. J Bone Joint Surg Am 1986;68:235-4
4. Errani C, Ruggieri P, Asenzio MA, et al. Giant cell tumorof the extremity: A review of 349 cases from a single institution. Cancer Treat Rev 2010;36:1-7

5. Bhatia S, Miszczyk L, Roelants $M$, et al. Radiotherapy for marginally resected, unresectable or recurrent giant cell tumor of the bone: a rare cancer network study. Rare Tumors 2011;3:e48

6. Siebenrock KA, Unni KK, Rock MG. Giant-cell tumour of bone metastasising to the lungs. A longterm follow-up. J Bone Joint Surg Br 1998;80:43-7

7. Thomas D, Henshaw R, Skubitz K, et al. Denosumab in patients with giant-cell tumour of bone: an open-label, phase 2 study. Lancet Oncol 2010;11:275-80

8. Balke M, Campanacci L, Gebert $\mathrm{C}$, et al. Bisphosphonate treatment of aggressive primary, recurrent and metastatic giant cell tumour of bone. BMC Cancer 2010;10:462 